\title{
VALIDATION OF A RAPID STOOL ANTIGEN TEST FOR DIAGNOSIS OF Helicobacter pylori INFECTION
}

\author{
Joyce Matie Kinoshita da SILVA, Cibele Aparecida VILLARES, Maria do Socorro MONTEIRO, Carlos COLAÚTO, Anibal Ferreira dos SANTOS \& Rejane MATTAR
}

\begin{abstract}
SUMMARY
The aim of this study was to validate the rapid lateral flow Helicobacter pylori stool antigen test (One step H. pylori antigen test, ACON laboratories, San Diego, USA; Prime diagnostics, São Paulo), using ${ }^{13}$ C-Urea Breath Test as the gold standard for $H$. pylori infection diagnosis. A total of 98 consecutive patients, asymptomatic or dyspeptic, entered the study. Sixty-nine were women, with a mean age of $45.76 \pm 14.59$ years (14 to 79 years). In the $H$. pylori-positive group, the rapid stool antigen test detected $H$. pylori antigen in 44 of the 50 positive patients (sensitivity $88 \%$; 95\% CI: 75.7-95.5\%), and six false-negative; and in the $H$. pylori-negative group 42 presented negative results (specificity $87.5 \%$; 95\% CI: 74.7-95.3\%), and six false-positive, showing a substantial agreement (Kappa Index $=0.75 ; p<0.0001 ; 95 \% \mathrm{CI}: 0.6-0.9)$. Forty four of fifty patients that had positive stool antigen were $H$. pylori-positive, the PPV of the stool antigen test was $88 \%$ (95\% CI: 75.7-95.5\%), and 42 patients with negative stool antigen test were $H$. pylori-negative, the NPV of the stool antigen test was $87.5 \%$ (95\% CI: 74.7-95.3\%). We conclude that the lateral flow stool antigen test can be used as an alternative to breath test for $\mathrm{H}$. pylori infection diagnosis especially in developing countries.
\end{abstract}

KEYWORDS: ${ }^{13} \mathrm{C}$-urea breath test; $H$. pylori stool antigen test; H. pylori diagnosis.

\section{INTRODUCTION}

Helicobacter pylori (H. pylori), spiral or curved gram-negative microaerophilic, flagellate bacilli has been considered the etiological cause of gastritis, peptic ulcer disease $\mathrm{e}^{21,24}$ and associated with the development of gastric cancer ${ }^{25}$.

The prevalence of $H$. pylori infection is different worldwide, depending on the socioeconomic status and sanitation conditions ${ }^{1}$; in the developed countries being under $40 \%$ and more than $80 \%$ in developing countries ${ }^{16}$, including Brazil where the prevalence varies from $65.6 \%$ in the city of Sao Paulo that has a high standard of living ${ }^{34}$, to $87 \%$ in the poor urban areas of Fortaleza, northeastern Brazil ${ }^{29}$.

The diagnosis of $H$. pylori infection can be achieved by invasive methods such as urease test, which has $97.4 \%$ sensitivity and $100 \%$ specificity ${ }^{32}$, widely used and performed in the endoscopy suite as a rapid indirect test to confirm the presence of $H$. pylori in biopsy samples, and histology of the Modified Giemsa stained gastric biopsies (96.2\% sensitivity $)^{18}$. Non-invasive methods, ${ }^{14} \mathrm{C}$ - urea breath test $\left({ }^{14} \mathrm{C} \text {-UBT }\right)^{22,23}$ and ${ }^{13} \mathrm{C}$ urea breath test $\left({ }^{13} \mathrm{C}\right.$-UBT), are considered gold standard ${ }^{19}$. Recently, a noninvasive diagnostic test based on the detection of $H$. pylori stool antigen has been developed. Some $H$. pylori stool antigen tests that use polyclonal antibodies to $H$. pylori have shown heterogeneous results $^{2,12,17}$. More recently, novel stool antigen tests based on monoclonal antibodies which could increase the accuracy of this test, have been developed ${ }^{2,8,12,14,15,33}$.

The non-radioactive isotope ${ }^{13} \mathrm{C}$-UBT is preferable to ${ }^{14} \mathrm{C}-\mathrm{UBT}^{3}$; however, the acquisition of Infrared has a cost that most places cannot afford, and that makes the stool antigen a cheaper alternative choice for eradication control ${ }^{2,15}$. It was recommended by the Maastricht III Consensus Report as a non-invasive test ${ }^{19}$.

The stool antigen tests based on immunoassay (ELISA) have been tested in several laboratories of the world, including in Brazil ${ }^{4,26-28}$, and the results have been satisfactory. In Brazil, previous validation of a monoclonal stool antigen test for diagnosis of $H$. pylori was reported in children ${ }^{27}$; however, the stool antigen test based on lateral flow chromatography has not yet been tested in adults. The major advantage of these tests is the cost, when compared to ${ }^{13} \mathrm{C}-\mathrm{UBT}$ and the possibility of being performed in any laboratory ${ }^{10,14,15,17}$.

The rapid stool antigen test (ACON laboratories, Inc, San Diego, USA) is a rapid 10-min assay based on lateral flow chromatography with polyclonal antibodies that detect $H$. pylori antigens present in human stool. Thus, the aim of this study was to evaluate the rapid Helicobacter pylori stool antigen test, using ${ }^{13} \mathrm{C}-\mathrm{UBT}$ as the "gold standard" method for $H$. pylori infection diagnosis. 


\section{MATERIAL AND METHODS}

Patients: This study was approved by the local Ethics Committee (CAPPesq 0311/2009). A total of 98 consecutive patients, asymptomatic or dyspeptic, entered the study after providing written informed consent. Sixty-nine were women with a mean age of $45.76 \pm 14.59$ years (14 to 79 years). None had taken antibiotics at least one month before the test or acid secretor inhibitors in the previous ten days. The interval between the tests for $H$. pylori infection diagnosis did not exceed 14 days. The stools were fresh and processed immediately. Patients were instructed to store the stools at $4-16^{\circ} \mathrm{C}$ until arrival at the laboratory.

H. pylori status: The H. pylori status was based on the results of ${ }^{13} \mathrm{C}$-Urea breath test, and ${ }^{13} \mathrm{C}$-Urea breath test was considered the gold standard to ascertain the $H$. pylori-positive and the $H$. pylori-negative groups.

${ }^{13} \mathbf{C}$-Urea breath (UBT): Patients had to avoid smoking and sparkling water or soft drinks on the day of the test and observe a 4-hour fast. ${ }^{13} \mathrm{C}$-Urea breath was performed using acid meal, composed of $75 \mathrm{mg}$ of ${ }^{13} \mathrm{C}$-labeled urea dissolved in $200 \mathrm{~mL}$ of orange juice. Breath samples were collected in aluminized plastic bag to determine the baseline value before ingestion of acid meal and at 30 minutes after ingestion of the juice. Breath samples were analyzed by infrared spectroscopy (IRIS DOC, Wagner Analysen Technik, Bremen, Germany). A DOB (Delta over baseline-value) $\geq 4.0 \%$ o was considered positive for $H$. pylori infection, as previously described ${ }^{17}$.

H. pylori stool antigen test by Lateral Flow Immunoassay: Specimens were tested using the stool antigen test (One step H. pylori antigen test device, IHP-602, ACON laboratories, Inc, San Diego, USA; Prime diagnostics, São Paulo, Brazil) according to the manufacturer's instructions (94.9\%-100\% sensitivity and 95.1-100\% specificity, according to the manufacturer). Briefly, small samples of stool specimens collected from three different parts of the stool sample were transferred to a vial with diluent, vigorously agitated and after two minutes of resting the tube, dropping around two to three drops into the round window of the test cassette. Reading was made after 10 minutes of incubation at room temperature, and based on the appearance of colored lines across the central window of the cassette, two lines, $\mathrm{C}$ (control) and $\mathrm{T}$ (test), indicated positive test, only one line in $\mathrm{C}$ indicated negative result. A pale colored line in $\mathrm{T}$ was also considered positive.

Statistical analysis: The statistical analysis was performed by Kappa index measure of agreement of diagnostic tests, and Chi-square using SPSS. Confidence intervals were calculated by Exact Binomial Test with program R 2.10.1.

\section{RESULTS}

Fifty of ninety-eight patients were positive according to UBT, being defined as $H$. pylori-positive, and 48 patients were negative according to
UBT and considered H. pylori-negative. In the H. pylori-positive group, the rapid stool antigen test detected $H$. pylori antigen in 44 of the 50 positive patients (sensitivity 88\%; 95\% confidence interval (CI): $75.7-95.5 \%$ ), and six false-negative; and in the $H$. pylori-negative group, 42 presented negative results (specificity 87.5\%; 95\% CI: $74.7-95.3 \%$ ), and six false-positives, showing a substantial agreement (Kappa Index $=0.75 ; p<0.0001 ; \mathrm{CI}: 0.6$ 0.9 ). Considering that 44 patients of 50 that had positive stool antigen were H. pylori-positive according to UBT, the positive predictive value of the stool antigen test was $88 \%$ (95\% CI: $75.7-95.5 \%$ ), and that 42 patients with negative stool antigen test were $H$. pylori-negative, the negative predictive value of the stool antigen test was $87.5 \%$ (95\% CI: 74.7-95.3\%), as shown in Table 1. Among six patients that had positive stool antigen test and negative UBT, four of them were eradication control.

\section{DISCUSSION}

H. pylori colonizes the human stomach during childhood ${ }^{26}$ and survives in the human stomach, the only niche known to date, for the lifetime of the carrier ${ }^{5}$. In most of the individuals $H$. pylori infection may be asymptomatic, causing chronic gastritis. Around 20\% to $30 \%$ of the infected individuals may develop peptic ulcer disease ${ }^{20}$, and less than $2 \%$ gastric cancer ${ }^{16}$. Gastrointestinal endoscopy has been widely performed for gastrointestinal disorders and $H$. pylori infection diagnosis ${ }^{20}$. Nonetheless, the Maastricht III consensus report recommended in primary care, a test and treat strategy using a noninvasive test in adult patients under the age of 45 with persistent dyspepsia. The urea breath test, stool antigen tests, and serological kits with a high accuracy are non-invasive exams which should be used for the diagnosis of $H$. pylori infection ${ }^{19}$.

For eradication control, ideally after three months of treatment, the breath test rapidly confirms the disappearance of $H$. pylori ${ }^{31}$, unlike the serological techniques, which need a prolonged period of time to confirm the eradication effect. Thus, because antibody titers can take up to six months to fall after successful treatment, serological tests cannot readily be used to assess the efficacy of $H$. pylori eradication regimens shortly after treatment ${ }^{8}$.

Even though the radiation exposure from ${ }^{14} \mathrm{C}$-urea breath test is less than $1 \%$ of that received from an upper gastrointestinal series ${ }^{22}$, the cost of a $\beta$ counter is low, and the test has $100 \%$ specificity and sensitivity ${ }^{23}$, the long half life $(5.730 \text { years })^{3}$ of ${ }^{14} \mathrm{C}$ restricts its use due to the environmental protection policy. That means ${ }^{13} \mathrm{C}$-urea breath test and the stool antigen test are the only choices of non-invasive methods for $H$. pylori-infection eradication control.

The development of non-dispersive isotope selective infrared spectrometers opened up a lower-priced analytical alternative for highresolution mass spectrometers with sensitivity and specificity of $95 \%$ in multiple studies and a meta-analysis including more than 3500 patients ${ }^{3}$. However, most of the Health Centers in Brazil cannot afford to pay for infrared spectrometers in foreign currency, even though the cost of

Table 1

Performance of the stool antigen test using UBT to define $H$. pylori-negative and $H$. pylori-positive groups

\begin{tabular}{lccccccccc}
\hline Group & Method & True positive & True negative & False positive False negative & Sensitivity & Specificity & PPV & NPV \\
\hline 98 & Stool antigen test & 44 & 42 & 6 & 6 & $88 \%$ & $87.5 \%$ & $88 \%$ & $87.5 \%$ \\
\hline
\end{tabular}


${ }^{13} \mathrm{C}$-urea is lower than the ${ }^{14} \mathrm{C}$-urea. Thus, the stool antigen test may be the only option of a non-invasive method of $H$. pylori eradication control in these Health Centers.

The stool antigen test may be performed by conventional immunoassay (EIA) using polyclonal antibodies ${ }^{4,6,7,10,13,17}$, showing sensitivity of $88.9 \%$ to $98.3 \%$ and specificity of $77.8 \%$ to $98.4 \%$, and by rapid lateral flow immunoassay using monoclonal antibodies ${ }^{10,12,14,15,33}$, presenting 52.5-94.6\% sensitivity, $55.5-98.4 \%$ specificity, $94.6 \%$ positive predictive value and $98.4 \%$ of negative predictive value $e^{2,10,12,33}$. The lateral flow immunoassay is useful for small laboratories that do not have equipment for performing the EIA and that work with few samples. The lateral flow immunoassay is faster than the conventional EIA that takes more than two hours to be performed; in addition, the cut-off value is still a matter of debate ${ }^{2.33}$.

We tested rapid lateral flow immunoassay stool antigen (a commercial immunoassay kit of ACON), using the ${ }^{13} \mathrm{C}$-urea breath test as the gold standard method, and detected a sensitivity of $88 \%$ and specificity of $87.5 \%$, presenting good agreement with the breath test $(\kappa=0.755)$, data consistent with those previously reported.

As the patients guaranteed that they had followed the instruction of avoiding proton pump inhibitors for at least ten days before the test, temporary inhibition of the growth would not be the cause of falsenegative results. Nonetheless, low colonization of bacteria in the stomach, and consequently, low concentration of antigens of $H$. pylori in the feces could not be enough to react in the test ${ }^{15}$, causing the false-negative tests. Coccoid form of $H$. pylori may explain the false-positive results that is the morphologic manifestation of bacterial cell death and does not mean an infection risk ${ }^{2}$; conversely, three patients with false-positive result were not eradication control; however, two of them had H. pyloripositive relatives sharing the same bathroom. Even though patients were instructed to collect the stools in sterile vials supplied by the laboratory, we cannot exclude the possibility of external contamination. Another possibility would be cross-reaction among the polyclonal antibodies of the test with antigens of bacteria from the intestinal flora.

KRAUSSE et al. $(2008)^{14}$ evaluated lateral flow rapid fecal antigen tests and found that the incubation time was an important factor for the reading of the result: readings at $30 \mathrm{~min}(76.9 \%)$ and $60 \mathrm{~min}(78.6 \%)$ had higher sensitivity than after $20 \mathrm{~min}$ (59.1), suggesting a new reading strategy: first interpretation at 15-20 min, and a long incubation of 30 min when the sample is negative for up to $20 \mathrm{~min}$. We also observed in some samples that turned up positive after 20 minutes of incubation (data not shown), that this strategy may increase sensitivity.

We conclude that the lateral flow stool antigen test can be used as an alternative to breath test for diagnosis of primary infection of $H$. pylori, especially in developing countries.

\section{RESUMO}

\section{Validação de teste rápido de antígeno fecal para diagnóstico de infecção por Helicobacter pylori}

O objetivo desse trabalho foi avaliar o teste rápido de antígeno de $H$. pylori nas fezes (One step H. pylori antigen test, ACON laboratories, San
Diego, USA; Prime diagnostics, São Paulo), usando teste respiratório com uréia marcada $\operatorname{com}^{13} \mathrm{C}$ (TRU- $\left.{ }^{13} \mathrm{C}\right)$, como padrão ouro. Noventa e oito pacientes assintomáticos ou com dispepsia participaram do estudo. Sessenta e nove eram mulheres; a média de idade dos pacientes foi de $45.76 \pm 14.59$ ( 14 a 79 anos). No grupo H. pylori positivo, o teste rápido detectou antígenos de $H$. pylori nas fezes em 44 dos 50 pacientes positivos (sensibilidade de 88\%; 95\% IC: 75.7-95.5\%), com seis falso-negativos; e no grupo $H$. pylori negativo, 42 apresentaram resultados negativos (especificidade de 87,5\%; 95\% IC: 74.7-95.3\%), com seis falso-positivos, mostrando concordância substancial (índice Kappa $=0.75 ; p<0.0001$; 95\% IC: 0.6-0.9). Quarenta e quatro dos 50 que tiveram teste de antígeno fecal positivo eram $H$. pylori positivos, sendo o VPP do teste $88 \%$ (95\% IC: $75.7-95.5 \%)$, e 42 pacientes com teste de antígeno fecal negativo eram H. pylori negativos, com VPN de 87,5\% (95\% IC: 74.7-95.3\%). Concluímos que o teste de antígeno fecal imunocromatográfico pode ser usado como alternativa ao teste respiratório para diagnóstico de infecção pelo H. pylori, principalmente em países em desenvolvimento.

\section{ACKNOWLEDGMENTS}

The authors thank Prime diagnostics and E-medical cientifica for providing four kits for the study.

\section{REFERENCES}

1. Ahmed KS, Khan AA, Ahmed I, Tiwari SK, Habeeb A, Ahi JD, et al. Impact of household hygiene and water source on the prevalence and transmission of Helicobacter pylori: a South Indian perspective. Singapore Med J. 2007;48:543-9.

2. Blanco S, Forné M, Lacoma A, Prat C, Cuesta MA, Latorre I, et al. Comparison of stool antigen immunoassay methods for detecting Helicobacter pylori infection before and after eradication treatment. Diagn Microbiol Infect Dis. 2008;61:150-5.

3. Braden B, Lembcke B, Kuker W, Caspary WF. ${ }^{13}$ C-breath tests: current state of the art and future directions. Dig Liver Dis. 2007;39:795-805.

4. de Carvalho Costa Cardinali L, Rocha GA, Rocha AM, de Moura SB, de Figueiredo Soares T, Esteves AM, et al. Evaluation of $\left[{ }^{13} \mathrm{C}\right]$-urea breath test and Helicobacter pylor stool antigen test for diagnosis of $H$. pylori infection in children from a developing country. J Clin Microbiol. 2003;41:3334-5.

5. Carroll IM, Ahmed N, Beesley SM, Khan AA, Ghousunnissa S, Moráin CA, et al Microevolution between paired antral and paired antrum and corpus Helicobacter pylori isolates recovered from individual patients. J Med Microbiol. 2004;53:669-77.

6. Dore MP, Negrini R, Tadeu V, Marras L, Maragkoudakis E, Nieddu S, et al. Novel monoclonal antibody-based Helicobacter pylori stool antigen test. Helicobacter. 2004;9:228-32.

7. Forné M, Domínguez J, Fernández-Bañares F, Lite J, Esteve M, Galí N, et al. Accuracy of an enzyme immunoassay for the detection of Helicobacter pylori in stool specimens in the diagnosis of infection and posttreatment check-up. Am J Gastroenterol. 2000;95:2200-5

8. Gisbert JP, de la Morena F, Abraira V. Accuracy of monoclonal stool antigen test for the diagnosis of $H$. pylori infection: a systematic review and meta-analysis. Am J Gastroenterol. 2006;101:1921-30

9. Gisbert JP, Pajares JM. Review article: ${ }^{13} \mathrm{C}$-urea breath test in the diagnosis of Helicobacter pylori infection - a critical review. Aliment Pharmacol Ther. 2004;20:1001-17.

10. Hooton C, Keohane J, Clair J, Azam M, O'Mahony S, Crosbie O, et al. Comparison of three stool antigen assays with the ${ }^{13} \mathrm{C}$-urea breath test for primary diagnosis of Helicobacter pylori infection and monitoring treatment outcome. Eur J Gastroenterol Hepatol. 2006;18:595-9. 
11. Kato S, Ozawa K, Okuda M, Fujisawa T, Kagimoto S, Konno M, et al. Accuracy of the stool antigen test for the diagnosis of childhood Helicobacter pylori infection: a multicenter Japanese study. Am J Gastroenterol. 2003;98:296-300.

12. Kato S, Ozawa K, Okuda M, Nakayama Y, Yoshimura N, Konno M, et al. Multicenter comparison of rapid lateral flow stool antigen immunoassay and stool antigen enzyme immunoassay for the diagnosis of Helicobacter pylori infection in children. Helicobacter. 2004;9:669-73.

13. Konstantopoulos N, Rüssmann H, Tasch C, Sauerwald T, Demmelmair H, Autenrieth I, et al. Evaluation of the Helicobacter pylori stool antigen test (HpSA) for detection of Helicobacter pylori infection in children. Am J Gastroenterol. 2001;96:677-83.

14. Krausse R, Müller G, Doniec M. Evaluation of a rapid new stool antigen test for diagnosis of Helicobacter pylori infection in adult patients. J Clin Microbiol. 2008;46:2062-5.

15. Kuloğlu Z, Kansu A, Kirsaçlioğlu CT, Ustündağ G, Aysev D, Ensari A, et al. A rapid lateral flow stool antigen immunoassay and ${ }^{14} \mathrm{C}$-urea breath test for the diagnosis and eradication of Helicobacter pylori infection in children. Diagn Microbiol Infect Dis. 2008;62:351-6

16. Kusters JG, van Vliet AHM, Kuipers EJ. Pathogenesis of Helicobacter pylori infection. Clin Microbiol Rev. 2006;19:449-90.

17. Lahner E, Vaira D, Figura N, Pilozzi E, Pasquali A, Severi C, et al. Role of noninvasive tests (C-urea breath test and stool antigen test) as additional tools in diagnosis of Helicobacter pylori infection in patients with atrophic body gastritis. Helicobacter. 2004;9:436-42.

18. Lunet N, Peleteiro B, Carrilho C, Figueiredo C, Azevedo A. Sensitivity is not an intrinsic property of a diagnostic test: empirical evidence from histological diagnosis of Helicobacter pylori infection. BMC Gastroenterol. 2009;9:98

19. Malfertheiner P, Megraud F, O’Morain C, Bazzoli F, El-Omar E, Graham D, et al. Current concepts in the management of Helicobacter pylori infection: the Maastricht III Consensus Report. Gut. 2007;56:772-81.

20. Marques SB. Prevalência de infecção pelo Helicobacter pylori associada às afecções diagnosticadas por endoscopia digestiva alta: análise retrospectiva de 1478 casos [dissertação]. São Paulo: Faculdade de Medicina, Universidade de São Paulo; 2009.

21. Marshall BJ, Warren JR. Unidentified curved bacilli in the stomach of patients with gastritis and peptic ulceration. Lancet. 1984;1:1311-5.

22. Marshall BJ, Plankey MW, Hoffman SR, Boyd CL, Dye KR, Frierson HF Jr, et al. A 20-minute breath test for Helicobacter pylori. Am J Gastroenterol. 1991;86:438-45.
23. Mattar R, Silva FM, Alexandrino AM, Laudanna AA. Validation of ${ }^{14} \mathrm{C}$-urea breath test for diagnosis of Helicobacter pylori. Rev Inst Med Trop Sao Paulo. 1999;41:3-7.

24. Mattar R, Marques SB, Monteiro MS, dos Santos AF, Yriya K, Carrilho FJ. Helicobacter pylori cag pathogenicity island genes: clinical relevance for peptic ulcer disease development in Brazil. J Med Microbiol. 2007;56:9-14.

25. Mattar R, Monteiro MS, Marques SB, Zilberstein B, Hashimoto CL, Carrilho FL. Association of LEC and tnpA Helicobacter pylori genes with gastric cancer in a Brazilian population. Infect Agents Cancer. 2010;5:1.

26. Parente JML, da Silva BB, Palha-Dias MPS, Zaterka S, Nishimura NF, Zeitune JM Helicobacter pylori infection in children of low and high socioeconomic status in northeastern Brazil. Am J Trop Med Hyg. 2006;75:509-12.

27. Raguza D, Machado RS, Ogata SK, Granato CF, Patricio FR, Kawakami E. Validation of a monoclonal stool antigen test for diagnosing Helicobacter pylori infection in young children. J Pediatr Gastroenterol Nutr. 2010;50:400-3.

28. Raguza D, Granato CFH, Kawakami E. Evaluation of the stool antigen test for Helicobacter pylori in children and adolescents. Dig Dis Sci. 2005;50:453-7.

29. Rodrigues MN, Queiroz DM, Rodrigues RT, Rocha AM, Luz CR, Braga LL. Prevalence of Helicobacter pylori infection in Fortaleza, Northeastern Brazil. Rev Saúde Publica. 2005;39:847-9.

30. Shimoyama T, Oyama T, Matsuzaka M, Danjo K, Nakaji S, Fukuda S. Comparison of a stool antigen test and serology for the diagnosis of Helicobacter pylori infection in mass survey. Helicobacter. 2009;14:87-90.

31. Silva FM, Navarro-Rodriguez T, Barbuti RC, Mattar R, Hashimoto CL, Eisig JN Helicobacter pylori reinfection in Brazilian patients with peptic ulcer disease: a 5-year follow-Up. Helicobacter. 2010;15:46-52.

32. Vaira D, Vakil N, Gatta L, Ricci C, Perna F, Saracino I, et al. Accuracy of a new ultrafast rapid urease test to diagnose Helicobacter pylori infection in 1000 consecutive dyspeptic patients. Aliment Pharmacol Ther. 2010;31:331-8.

33. Yang HR, Seo JK. Helicobacter pylori stool antigen (HpSA) tests in children before and after eradication therapy: comparison of rapid immunochromatographic assay and HpSA ELISA. Dig Dis Sci. 2008;53:2053-8.

34. Zaterka S, Eisig JN, Chinzon D, Rothstein W. Factors related to Helicobacter pylori prevalence in an adult population in Brazil. Helicobacter. 2007;12:82-8.

Received: 22 January 2010

Accepted: 27 April 2010 